\title{
Street Law - It Is More than Just Another Class
}

\author{
An Interview with Marilyn Cover and Jennifer Bloom
}

Marilyn Cover, JD, a 40-year veteran of teaching the Street Law Seminar class at Lewis \& Clark Law School.

Jennifer Bloom, JD, 16-year-veteran of teaching Street Law at the University of Minnesota Law School, following 15 years teaching Street Law at Hamline University School of Law

\section{Q: How is Your Street Law Course Organized?}

A-Marilyn: The Street Law program at Lewis \& Clark includes not only the weekly classes between law professor and students, but also weekly meetings with law students teaching in high school classes. The law school class is offered as a credit/no credit class. We use the Street Law text covering Intro to Law, Criminal \& Juvenile Law and Individual Rights and Liberties in the fall semester and the civil law units- torts, consumer and family law in the spring semester. Between 3040 law students participate each year. 
A-Jennifer: Like many other Street Law courses in the United States, the Minnesota Street Law seminar consists of a small class of 14 students gathering for a weekly twohour seminar. During this time, law students explore the history and goals of Street Law and participate in engaging teaching strategies (mock trial, moot courts, continuums, small group, ranking, and many others). Every teaching strategy is layered over legal content (first amendment, rights of the accused, employment, sexual harassment, consumer, etc.) to create effective and interesting lessons. As we proceed through the semester, the students build their collection of tried and true law-related education tools. Students share their engaging lessons when they teach 10 hours in area high schools. They are paired with experienced law and civics teachers and together select topics that complement the teacher's curriculum. Law students review the available lessons in the Street Law collection and elsewhere, revise as needed, present, and share reflections on the lesson's success or need for improvement. Every law student also creates an original lesson that is tried with classmates during the weekly seminar.

\section{Q: How is Street Law Different from Other Law School Classes?}

A-Marilyn: I have seen a lot in my 40 years. Street Law is very different from other law school classes and those differences have far-reaching benefits. 
Street Law tends to attract law students who are interested in the practical application of the law, being out in the community, and interacting with youth. My sense is that the law students have a pre-existing sense of altruism. In my Street Law program, law students have the unique opportunity to have hands-on classroom experiences with youth in their communities, and that helps fill their need to do good works.

A-Jennifer: When Street Law students walk out of their first class of the Street Law Seminar at the University of Minnesota Law School, they know at least one goal of the course ${ }^{1}$. After learning the course components and requirements through an "Each One Teach One" and a "Jeopardy" game², they usually can correctly answer the final Jeopardy question: "Street Law is different from most other law school courses for this reason." Answer: "What is fun?"

\footnotetext{
${ }^{1}$ These goals are:

1) Understanding of substantive law;

2) Knowledge of legal procedures;

3) Ability to Communicate;

4) Skills in solving legal problems and client-centered lawyering;

5) Planning and Preparation;

6) Skills in Self-Assessing and Evaluating;

7) Development of a Sense of Professionalism;

8) Development of an Appreciation of the Role of the Lawyer in the Community.

2 "Each One Teach One" is an activity that asks students to teach other students about the facts of the course. Jeopardy game is similar to a television show of that name. Students compete in teams to be the first to answer a question correctly. The questions concern facts of the course. These two strategies are more fun and more effective than a lecture teaching basic information about the course. The final question reinforces the commitment to make learning fun.
} 


\section{Q: Teaching is Hard. How do you prepare students to be successful in the classroom?}

A-Marilyn: Unlike the typical law school class, the seminar setting of my weekly class is an intimate one. Our discussions focus on how to convey legal concepts in lesson plans and how students learn. One student may describe an enormously successful teaching strategy in one class only to find that it falls flat in another. Conversations around situations like this are layered and insightful. I also observe law students teaching in their high school classes.

When in high school classrooms, law students' lessons focus, for example, on search and seizure of students' backpacks, or reading one's first apartment lease. Whatever the topic, law students experience real dialog about real issues in the daily lives of high school students. In doing so, they gain skills that are easily transferrable to the workplace. The seminar discussions include public policy, trial practice, and communication skills with clients as part of the lessons the law students prepare for their high school students. When law students discover that they are able to convey complex legal content to the lay public - high schools students are, after all, the perfect petri dish for communication - they gain incalculable confidence. That ability to clearly communicate, and to do so with confidence, serves them well in their legal careers. 
A-Jennifer: "To teach is to learn twice." Joseph Joubert

There is nothing like preparing for a presentation that inspires a person to update their subject matter knowledge. Street Law students take their responsibilities seriously to provide accurate information to their high school students. The risk of getting it wrong is stressed in the weekly Street Law seminar. For example, when high school students participate in a misleading lesson on what to do when stopped by the police, a misunderstanding of their rights can be devastating. Street Law students frequently discuss how their understanding of the law increased when they prepared to teach it. Students research, write and present lessons to their Street Law classmates where content is reviewed and potential misunderstandings or mistakes about the law are identified and corrected. Street Law faculty, both lawyers, review the final lesson. In addition to the lesson students write, they have access to hundreds of lessons written by other Street Law students over the years. Students are asked to update the law before they use the lesson and are asked to share the updated lesson for others to use.

Another requirement of our Street Law seminar requires small groups of law students to develop and present a lesson to the other Street Law students. These lessons include an expanded presentation of the law designed for law students shy 
in content knowledge. After each lesson, all law students share ideas for improving the lesson and using it in different settings including with high-needs students. Insights learned during this informal discussion build skills for teaching law to their high students and with future clients.

Students also learn the importance of preparation and practice. We all enjoy watching the delivery of a television show's awe-inspiring closing argument. It looks so easy. We also know it's not. When a high school class meets for 50 minutes, law students cannot be scrambling to figure out the next step. It is important for them to plan how they will describe the law to people unfamiliar with the law, checking for understanding and making adjustments as they go.

\section{Q: How Else Do Law Students Benefit from Street Law Beyond the Classroom?}

A-Marilyn: Many law students leave Street Law with an indelible connection to the high school where they taught. Some develop a predisposition to seek other opportunities to serve their communities. The seed for giving back to the community is sown in the Street Law seminar. Many of my former students practice in the Portland area. I see them working in an array of non-profit organizations and public entities. 
My role as professor expands, therefore, to that of advisor, counselor, and confidante. As a result of our interactions through papers, classes, lessons, observations and discussions, by the semester's end I know these students. I am often, even years later, sought out for purposes of a reference or recommendation for potential employment. These are rich relationships and worth nurturing.

A-Jennifer: Much of the law school experience in other courses consists of individual work. Friendships develop and some students study together, however so often the law students' success in law school depends on themselves alone. This is not the case in Street Law. Street Law students usually teach together. They work in partnership with the classroom teachers to select topics that are interesting to the high school students and support the teacher's curriculum plan. They select dates and times. They meet the students before they begin teaching, introducing themselves. They are professionals. My law students have often said that Street Law lets them do what they came to law school to do. It restores them. They want to help solve problems and Street Law provides an avenue for them to share what they know to improve the lives of the students they teach. 


\section{Q: How Does the Community Benefit from Street Law Students?}

\section{A-Marilyn:}

In my day job, I run Classroom Law Project (CLP), a statewide non-profit organization dedicated to civic education for kindergarten through 12-grade (ages 4-18 year olds). The Street Law seminar class and its students are the lynchpin of CLP. CLP has eleven different programs ranging from the statewide high school mock trial competition, to courthouse tours for 4,000 students annually, to weekly online current events viewed by thousands of educators. All programs rely on volunteers. When I assign law students to local high schools, the equation is greater than $1+1$. Benefitting from the connection are not only the law school and high school students, but also the high school teachers and administrators, the law school, Classroom Law Project, and the broader legal community.

When my wet-behind-the-ears law students eventually evolve into seasoned law professionals, there is meaningful citizen engagement to be found. Among my former students are lawyers and civic leaders. They are judges on Oregon's circuit and appellate benches. They are in the state legislature. They are members of Classroom Law Project's board of directors. When I need volunteers for our next event - speakers, scholars, judges, guides - I know who to call. 
I have taught two semesters of Street Law every year for the past 40 years. At roughly 30 students per year, there are about 1200 alumni. They are ambassadors for Classroom Law Project, the law school, the high school, the community, or all of the above. In any case, another 30 potential new volunteers are added to my list every year.

A-Jennifer: One of the more significant Street Law goals is contribution to the community. Law students enroll in Street Law because they want to give back and the best way to do that is to share their new knowledge with others in need.

\section{Q: Any Final Thoughts?}

A-Marilyn: Classroom Law Project's mission statement is, “...individuals, educators, lawyers, and civic leaders building strong communities by teaching students to be active citizens." Street Law serves that mission. From law student to high school student to teacher, from lawyer to volunteer to legislator, communities are strengthened. Street Law is making a difference. 
A-Jennifer: I am also the executive director of Learning Law and Democracy, a Minnesota non-profit organization that sponsors programs to foster civic learning, teaching what it takes to tackle the most important role of citizen. Because in a selfgoverning society, we all must step to the plate to do our part to advance the constitutional experiment. Street Law helps build the leaders we need. At the end of every Street Law course, I ask the students to reflect on what they have learned that will help them be a better lawyer. Without exception over the many years, they talk about how they want to be leaders in their communities. They want to get involved in improving civic education in their schools. They want to make a difference. 